\title{
Política, responsabilidade social e controle
}

Todo debatedor corre o risco de relegar - texto objeto do debate e de acabar apresentando uma diferente versão do tema confiado a outrem. Consciente de tal risco. restringirei os comentários às lacunas que um trabalho desta natureza dificilmente poderia preencher.

A) Embora haja uma nítida tendência no sentido do fortalecimento da ação do Congresso - restrita até recentemente à identificação de problemas nacionais (e locais) e à tradução da crítica e do debate parlamentar em algumas medidas legais - o Poder Executivo continuará, como em outros países, a manter parte considerável da iniciativa no processo legislativo. Apesar do atual desencanto com modelos, esquemas e fórmulas de conduta social, anteriormente identificados com progresso e modernização, é improvável que seus inevitáveis sucedâneos se originem em setores outros que a burocracia. Maior participação política poderá resultar em maiores controles sobre a Administração Pública. Entretanto, como se tem verificado em sociedades pluralistas, a burocracia busca sempre novas formas de associação, até mesmo com a clientela de seus serviços, para aumentar a influência exercida em decorrência de conhecimentos especializados e da familiaridade com a rotina dos misteres públicos ${ }^{1}$ A complexidade crescente da vida moderna, longe de reduzir o campo de atuação da burocracia à tarefa de mera executora das politicas do governo, exigirá tratamento especializado, conseqüentemente profissional, de diversos temas, outrora inexistentes nas agendas dos detentores de cargos eletivos ${ }^{2}$.

B) A recessão rouba-nos as perspectivas de progresso. Torna-se, por conseguinte. mais difícil acreditar que o precedente de paises avançados encerre ensinamentos para a nossa sociedade. Apesar das compreensiveis frustrações e do justificado pessimismo, há razão para crer numa evolução rumo à melhoria no cumprimento das missões governamentais. É provável que a institucionalização dos partidos politicos brasileiros venha a exigir que o sistema de espólios se sobreponha a valores associados com o mérito na administração de pessoal. Outros paises conviveram longamente com o regime do "pistolão", antes de disporem de um serviço público efíciente e confiável. 
C) O tracasso dos regimes autoritários nas tentativas de modernizar a administração pública brasileira não poderá ser atribuído apenas à ideologia, aos valores que deveriam, em tese pelo menos, legitimar as iniciativas reformistas. Em paises como a Inglaterra e os Estados Unidos, onde tais iniciativas lograram êxito, outras variáveis exerceram papel de fundamental importância na consolidação de um serviço público civil digno deste nome.

As causas do insucesso do governo brasileiro em modernizar sua burocracia tradicional foram amplamente estudadas por Kleber Nascimento e outros autores. Os motivos do fracasso são complexos, mas a inexistência de uma estratégia política e administrativa para formular e, sobretudo, para implementar a reforma merece destaque entre eles. A ausência de debate político, inviável no Brasil de então. impediu que as propostas de reforma ganhassem adeptos nos diversos segmentos da sociedade. Metas ambiciosas, sobretudo, acabaram por comprometer programas que poderiam prolongar-se em futuras adminstrações ${ }^{3}$.

D) Contrastando com estas particularidades do esforço modernizante no Brasil. cabe ressaltar as variáveis que se associam ao êxito do movimento reformista inglês, que resultou num serviço público civil, cuja eficiência líderes de inúmeros países aprenderam a admirar ${ }^{4}$.

No século passado, a preocupaçāo com economia, com a melhor utilização dos recursos públicos, suscitou a instalação de diversas comissōes de inquérito sobre a administraçăo pública inglesa. Uma delas, porém, produziu, em 1854, um relatório que gradualmente fornecería a base ideológica da reforma. Segundo Stafford Northcote e Charles Trevelyan, autores do relatório, o serviço público inglês, embora indispensável à condução do país, tornara-se o refúgio dos medíocres, indolentes e incapazes. A fonte dos males se encontraria no processo seletivo e na ausência de critérios para promoção. 0 remédio estaria na seleção através de exames competitivos; na separação do trabalho mecânico (rotineiro) das tarefas intelectuais; na promoçāo por mérito

Entre a divulgação do relatório e a plena aceitação de suas recomendações passaram-se décadas. As reaçöes desfavoráveis às suas conclusōes, porém, desmoronariam em decorrência de fatores diversos. O primeiro deles foi o profundo descontentamento do público ante a incompetência da administração civil e militar durante a Guerra da Criméla (1854-56). Exigia-se, então, que se formulasse uma reforma política e administrativa. A Associação da Reforma Administrativa clamava por nada menos que uma "regeneração política", que pusesse fim aos privilégios da aristocracia e permitisse à classe média acesso ao poder. Tais demandas não seriam atendidas a curto prazo. Além disso, a Comissão de Serviço Civil, então críada, só começaria a trabalhar, a pleno vapor, quando Gladstone, já primeiro-ministro, introduziu, em vários ministérios, o sistema de seleção através de concursos (1870).

O caráter gradual, parcial e contínuo do movimento reformista contribuiu para vencer resistências no parlamento e na administração pública. A passagem de um regime de espólio para o sistema do mérito deu-se num período de expansão do eleitorado e de crescente mobilidade geográfica e social. Ademais, a "causa" da reforma administrativa conjugava-se perfeitamente com as mudanças que vinham ocorrendo no sistema educacional. As universidades înglesas viram nos novos métodos de seleção uma rara oportunidade de aumentar sua participação nos negócios do Estado.

A conveniência da retorma para líderes lỉberais como Gladstone residia na possibilidade de combinar os interesses da aristocracia com os da classe média. A reforma 
administrativa, em poucas palavras, ajustavase não só às mudanças sociaís como às condicões políticas e educacionais do final do século passado. Seus promotores, dentro e fora da administração pública, mostraram-se atentos a tal realidade tanto na fase de sua formulação quanto na de implementação, fase esta em que muitos propósitos da reforma se desvirtuam, dando lugar a conseqüênclas indesejáveis e a resultados perversos

E) Se o gradualismo foi uma caracteristica marcante da profissionalizaçăo do serviço público civil inglês, o mesmo se poderia dizer da implantação do sistema do mérito nos Estados Unidos, não fosse pelo assassina. to do Presidente James Garfield em 1881 que precipitou a assinatura da Lei Pendleton. em 1883. A Lei, que estabeleceu a Comissāo do Serviço Civil, fol fruto de um longo periodo de debates, alimentados por diversas organizações, inclusive pela Liga Nacional de Reforma do Serviço Civil. Apesar de tão grandes campanhas، a Comissão do Serviço Civil iniciou seus trabalhos colocando sob - regime do mérito apenas dez por cento dos cargos públicos então existentess

F) Para concluir, convém lembrar que das três missões desempenhadas pelo governo brasileiro, somente a empresarial foi objeto de maiores atenções e recursos financeiros, nas últimas décadas. Se são espetaculares os abusos praticados por al. gumas das empresas governamentais, igualmente espetaculares têm sido os resultados econômicos alcançados por várias delas ${ }^{6}$. As demais missões, a da prestação de serviços públicos tradicionais e a de regulação de transações econômicas em defesa do consumidor, que se sujeita ao arbítrio de mono. pólios públicos e oligopólios controlados por conglomerados transnacionais, estão a exigir um tratamento político inteligente, sério e contínuo. Trata-se de uma tarefa que desafia não só o governo. mas outros segmeńtos relevantes da sociedade brasileira. $E$ isso que parecem sugerir as experiências bem sucedidas de outros paises.

\section{Notas}

1. Ver a este respeito ROURKE, Francis E. Bureaucracy, Politics, and Public Policy. Boston, Little, Brown and Company, 1969.

2. FOSTER,Gregory D. Law. Morality, and the Public Servant", Public Administration Review, Vol. 41, nọ 1, 1981, p. 29.

3. NASCIMENTO, Kleber, Reflexões sobre estratégia de reforma administrativa: a experiência federal brasileira", Revista da $\boldsymbol{A} d$ ministação Pública, 10. Semestre. 1967 p. $11-50$.

4. A experiência inglesa na área de modernização administrativa é competentemente tratada por Fichard A. Chapman e J. R. Greenway, em The Dynamics of Administrative Reform. Londres, Croom Helm، 1980

5. Willian E. MOSHER, J. Donald Kingsley e O. Glenn Stahl, Public Personnel Administration, New York, Harper e Brothers, 1950, p.25-27.

6. CARVALHO, Getúlio. The Role of the Public Sector in 8razil", Public Enterprise, Vol. 2, no 1. 1981, p. 31-40. 